said before I shall be very careful not to take too much." It appears, therefore, that as a therapeutic dose $\frac{1}{10} \pi$ th grain of nitro-glycerine (or from to 1 milligramme) is sufficient to begin with, but it may be increased. The maximum dose is not known. The tablets have never been proved to be dangerous to life. There can be no question about their activity properly prepared. To any one unaccustomed to their use a tablet containing $\frac{1}{1} \frac{1}{0}$ th grain will canse throbbing in the temples in less than two minutes.

$$
\begin{aligned}
& \text { I Im. 24th, } 1896 . \quad \text { WM. Mirs, yours obediently, } \\
& \text { WARTINDALE. }
\end{aligned}
$$

\section{"EDUCATION AND INFECTION."} To the Editors of THE LANCET.

SrRs, - I thank you for your courteous and valuable criticism in TFE LANCET of Aug. 22nd, of what I certainly meant to be a leading idea in my articles on the "Prevention of Tuberculosis," published in recent numbers of the Medical Magazine. Having a strong belief in its truth I cannot but urge on those who will listen to me the view that very great good would come from making the older school children, all over the kingdom, familiar with the laws which we know control the spread of infective disease, so far as they could be taught in simple words. You ask: "But how are such right ideas to be imparted?" I venture to suggest, in outline, the following plan:-Many senior students of medicine could, and I think would willingly, give the necessary information to schoolmasters and to school children. Some of the younger and a few of the older medical men would, I feel sure, willingly give of their time to help on so good a work. All this could be done for a moderate amount of money. I am very far from sug. gesting that another public service should be added to the far too many already done for no pay by medical men. By-andby the schoolmaster would, in this way, have learned enough to teach his pupils the rudiments of the laws which control the spread of infections; and when this could be done then would cease the extra expense incurred in the first instance to provide for the payment of the special medical teachers. One of the earliest outcomes of this special teaching would be the growth of a literature dealing with the subject of the communicability of diseases, and written in such language as would, in due time, bring home to arerage intellects a sound working knowledge of how the spread of disease can be prevented.

You say, Sirs, "it is safe to conclude that a large number instructed in the theory and facts of infection will receive very wrong ideas indeed." This is most true; but will you point out any new and important teaching, especially any new medical teaching, from which have not sprung heavy crops of wrong ideas? These wrong ideas I have long regarded as among the great helps to the gradual diffusion of right ideas. Sensible people learn much from their own errors, and from the errors of others. In the long run it is the views of the sensible people which, in matters like this, lead public opinion. There can be no doubt that withou the support and active help of public opinion no teaching of the kind I ask for will ever be given in our schools. In no slight degree it is what is being taught to-day in our schools which will profoundly influence the opinions and, consequently, the actions of the next generation of our fellow countrymen. If this is true--and who doubts it?---surely it is plainly our duty to do our very best, in public as well as in private life, to see that the art of keeping infective diseases out of our homes is well taught to our children.

London, Aug. 22nd, 1896 I am, Sirs, yours faithfully,

\section{HIGH TEMPERATURE AFTER CHILDBIRTH. To the Editors of THE LANCET.}

Sies, - In the very practical and valuable paper on Paerperal Fever by Dr. Byers, published in 'The LAxce'T of Aug. 22nd, the writer, after enumerating certain complications of the puerperal state, doubts whether constipation is ever a cause of fever, and concludes that it is on the whole rare to have fever and quick pulse from any other cause than infection. My midwifery experience is small, but I have met with one case of fever from constipation and with more than one case of fever not due to either infection or obvious complication. When encamped in the desert on the borders of the Nile 1 had to attend an officer's wife in her first confinement. She was a healthy, vigorous woman and had an easy, normal labour a small perineal tear was treated with one stitch. The temperature was $102^{\circ} \mathrm{F}$. the evening of the day of delivery, $103^{\circ}$ the second night, and $105^{\circ}$ the third. The patient felt well all the time and had no other unfavourable symptoms. The bowels acted slightly on the third day after taking pills, but in the night following she passed a copious, foul-smelling motion, and next morning and evening the temperature was $102^{\circ}$, and then gradually returned to normal, and the patient had a speedy convalescence. Another case of non-septic high temperature was in a near relation. I was so much alarmed that I called in Dr. Matthews Duncan, who comforted me by making light of a rise of temperature when, as in this case, there were no other unfavourable symptoms. The rise on this occasion, I have no doubt, was simply due to nervous excitement; this patient was also a primipara. I believe that in many adults, as in children, the temperature is liable to rise from very slight causes. I am glad Dr. Byers points out the danger of antiseptic douches, and does not advise their routine employment in normal cases. Several of the cases of puerperal septicæmia I have had to do with (not in my own practice) have occurred in the course of very careful antiseptic treatment, including bichloride douches.

I am, Sirs, yours faithfully,

SIDNeY Davies, M.A., M.D. Oxon.

Plumstead, Aug. 24th, 1896.

\section{"MOTOH CARS."}

\section{To the Editors of THE Lancer.}

Sins,-Now that the Motor Car Act has had the Royal assent and become law it would be a great boon to the medical profession generally if you would depute a representative to examine into and report upon the best form of cars for town and country. There is no doubt that they will be most extensively used, and especially by medical men, to whom travelling expenses are an important item. Having visited patients in pretty well every possible way, it occurs to me to make the suggestion that the smaller cars should be of the safety bicycle and country rotary tricycle types; the latter might have a detachable extra seat, arranged so that two can sit back to back; this latter form of tricycle I have always found so perfect and thoroughly safe in the steering and sufficiently narrow to go through any doorway for temporary housing in case one should be detained for some hours at a case.

I am, Sirs, yours faithfully,
Bournemo
F. W. CoRY.

I am, Sirs,

*** We may point out to our readers that we have already touched upon the subject in our columns. In THE LArCET of Jan. 4th, 1896, page 63, will be found an account of the Exposition Internationale de Vélocipédie et de Locomotion Auto-mobile held in Paris in December, 1895, and at page 647 of the same volume there is an article giving the essential features which should characterise auto-cars for medical men. Other references to this subject will be found at pages 881 and 1261 of the same volume.--ED. L.

\section{"WHY IS THE LEFT HEART STRONGER 'IHAN THE RIGHT?" \\ To the Editors of THE LANCET.}

SIns,-Unless I greatly misunderstand him Dr. H. Campbell in his recent article with the above title and in his reply to Dr. Morison ${ }^{1}$ is leaving out of consideration one of the most important factors in the physics of the circulationviz, gravity. Surely it is gravity that makes the great difference between the work required of the left heart and that of the right? The left heart has to drive blood to the top of the skull some thirteen to fourteen inches abore the aortic valves, while the right heart has merely to drive it to the top of the lungs, some three to four inches above the pulmonary valves; and the engineer of any water company will tell you the difference in pressure and power required to deliver water on the fourth storey of a house as compared with ten feet above the pavement. 